\title{
Pesticide exposure as a risk factor for lymphoproliferative disorders in adults
}

\author{
E.A. Salem, ${ }^{1}$ M.M. Hegazy ${ }^{2}$ and E.A. El Khouley ${ }^{3}$
}

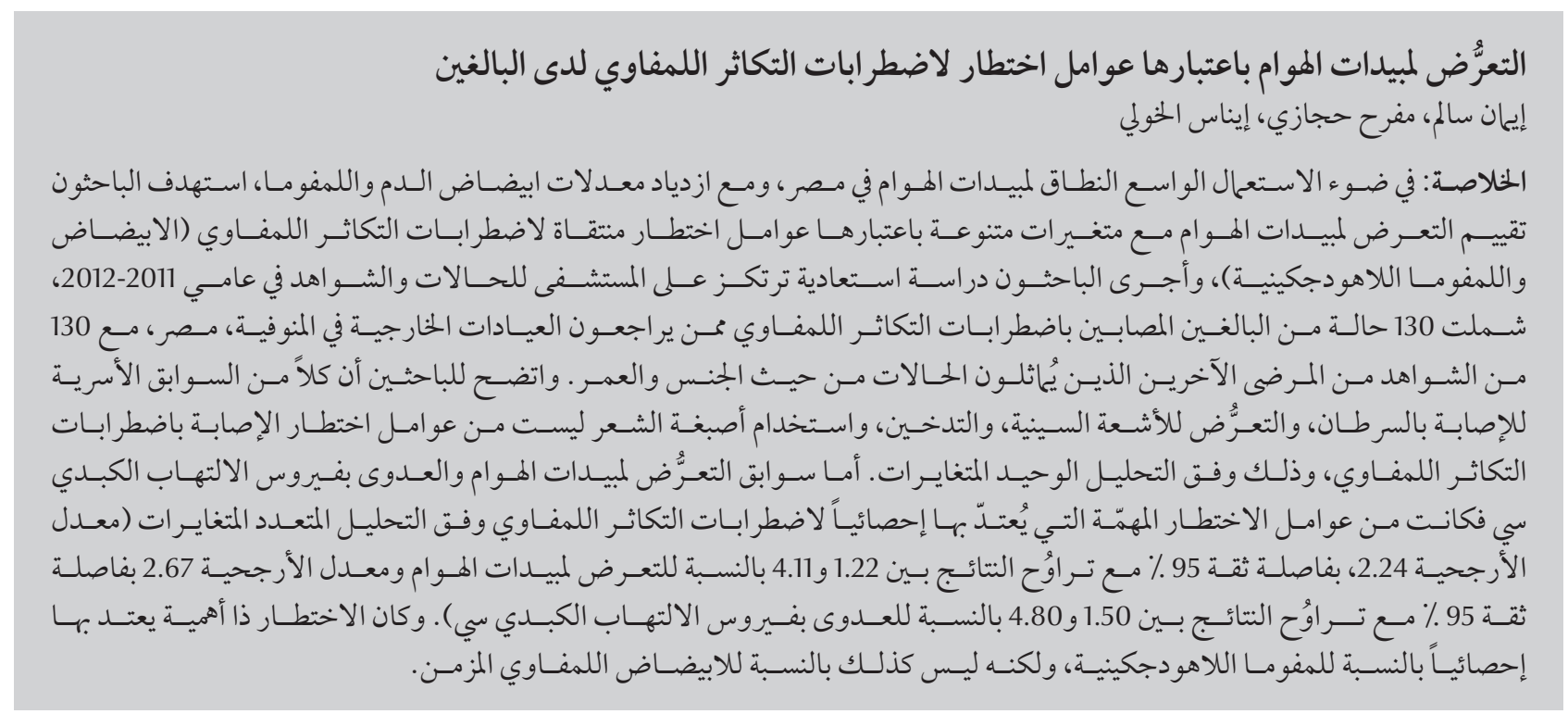

ABSTRACT In view of the widespread use of pesticides in Egypt and the increasing incidence of leukaemia and lymphoma we aimed to assess pesticide exposure and other selected variables as risk factors forlymphoproliferative disorders (leukaemia and non-Hodgkin lymphoma). In a hospital-based, retrospective, case-control study in 20112012, adult cases of lymphoproliferative disorders $(n=130)$ were recruited from outpatient clinics in Menoufia, Egypt, while controls $(n=130)$ were age- and sex-matched fracture patients. Family history of cancer, exposure to $\mathrm{X}$-rays, smoking and use of hair dyes were not risk factors for lymphoproliferative disorders in univariate analysis. History of exposure to pesticides and HCV infection were significant risk factors for lymphoproliferative disorders in multivariate analysis $(\mathrm{OR}=2.24 ; 95 \% \mathrm{Cl}: 1.22-4.11$ and $\mathrm{OR}=2.67 ; 95 \% \mathrm{Cl}: 1.50-4.80$ respectively). The risk was significant for cases of non-Hodgkin lymphoma but not chronic lymphocytic leukaemia.

\section{Exposition aux pesticides en tant que facteur de risque des maladies lymphoprolifératives chez l'adulte}

RÉSUMÉ Étant donné l'utilisation largement répandue des pesticides en Égypte et l'incidence croissante de la leucémie et dulymphome, nous avons tenté d'évaluerl'exposition auxpesticides et d'autresvariablessélectionnées en tant que facteurs de risque des maladies lymphoprolifératives (leucémie et lymphome non-hodgkinien). Dans une étude cas-témoins rétrospective menée en milieu hospitalier en 2011-2012, des adultes atteints de maladies lymphoprolifératives $(n=130)$ ont été recrutés dans des services de consultations externes à Menoufia (Égypte), tandis que les témoins appariés pour l'âge et le sexe $(n=130)$ recrutés souffraient de fractures. Des antécédents familiaux de cancer, d'exposition aux rayons- $X$, de consommation de tabac et d'utilisation de teintures capillaires ne constituaient pas des facteurs de risque des maladies lymphoprolifératives selon une analyse univariée. Des antécédents d'exposition aux pesticides et d'infection par le virus de l'hépatite C étaient des facteurs de risque importants de certaines maladies lymphoprolifératives à l'analyse multivariée (OR = 2,24; IC à 95 \% : 1,22-4,11 et $\mathrm{OR}=2,67$; IC à $95 \%$ : 1,50-4,80 respectivement). Le risque était significatif pour les cas de lymphome nonhodgkinien mais non significatif pour la leucémie lymphocytaire chronique. 


\section{Introduction}

Lymphoproliferative disorders are a heterogeneous group of malignant clonal proliferations of lymphocytes. They include disorders of B-, T- and NK-cell lineages all of which are further classified as distinct entities including chronic lymphocytic leukaemia (CLL), non-Hodgkin lymphoma (NHL), Hodgkin lymphoma, Waldenström macroglobulinaemia and multiple myeloma (1). NHL is a heterogeneous group of over 20 different $\mathrm{B}$ - and $\mathrm{T}$ cell neoplasms affecting the immune/ lymphatic system and arising primarily in the lymph nodes (2). Egypt has one of the highest incidence of lymphoma in the world, mainly NHL, which is higher than even the United States of America (USA) $(2,3)$ as well as other developed nations, where Hodgkin lymphoma are more common. In Egypt, NHL is the second most common cancer in adults, and lymphoma is the most common cancer in children (4).

The reasons for the increase in NHL are largely unexplained. A known predisposing factor that is strongly associated with NHL is immunosuppression (5). Several other risk factors have been identified, including exposure to infectious agents and chemical toxins $(6,7)$. Pesticides, which are widely used in agriculture, comprise a wide variety of chemicals mainly used to control damage to plants from insects (insecticides), mould (fungicides) and weeds (herbicides). In Egypt, several pesticides including organophosphate, carbamate and pyrethroid insecticides, fungicides and herbicides are commonly used to increase agricultural productivity (8). Organophosphate pesticides represent more than $80 \%$ of the total insecticides used in Egypt (9). While many pesticides are carcinogenic in animals and can act through several mechanisms to cause cancer in animals, their role in human carcinogenesis remains has not been fully clarified (10). A significant association between NHL and agricultural use of organophosphate and carbamate pesticides has been reported in studies from the USA (11), Israel (12) and Australia (13). Considering the widespread use of pesticides in Egypt, together with an increasing incidence of leukaemia and lymphoma, it is important to investigate whether there is an association between pesticide exposure and lymphoproliferative disorders or not.

This study aimed to assess pesticide exposure as a risk factor for lymphoproliferative disorders (leukaemia and NHL) in adults and to study the possible role of other risk factors for leukaemia and NHL in adults, including hepatitis $\mathrm{C}$ virus (HCV) infection, family history of cancer, smoking, exposure to X-rays and use of hair dyes.

\section{Methods}

This was a hospital-based, retrospective, case-control study carried out from 1 April 2011 to 31 October 2012. The study was limited to adults as the epidemiology of childhood lymphoproliferative disorders differs markedly from that of adults regarding specific causes such as post-transplantation conditions or specific infections such as Epstein-Barr virus (14).

\section{Subjects \\ Patients}

Cases of lymphoproliferative disorders ( $n=130)$ were recruited during the period of the study from patients attending outpatient clinics at the department of oncology, Menoufia University Hospital. The Hospital is a tertiary care centre for Menoufia Governorate, Egypt and these clinics provide outpatient care regarding diagnosis and follow up for patients with a variety of malignancies of varying acuity levels. Patients included in this study were over the age of 18 years; $85 \%$ of those who were approached consented to participate in the study. They were diagnosed as CLL or NHL after a clear diagnosis which was validated by the clinical oncologist mainly with the help of the surgeons (for biopsy taking), pathologist (for biopsy reading and immuophenotyping), clinical pathologist (for laboratory data) and radiodiagnosis physician (for imaging). To avoid immunosuppression in these patients all cases were selected before initiation of chemotherapy. The studied cases included 23 cases of CLL and 107 cases of NHL.

\section{Diagnostic criteria}

The diagnosis of CLL was based on the following (15): blood count (for presence of lymphocytosis, i.e. median values $30-50 \times 10^{9}$ of lymphocytes $/ \mathrm{L}$ ) ; bone marrow biopsy (bone marrow is usually hypercellular but can be normocellular; the most characteristic feature is the presence of at least 30\% mature-appearing lymphocytes); immunophenotyping (more than 95\% of all cases of CLL have a B-cell phenotype with monoclonality by light-chain restriction); and cytogenetic and molecular findings (a number of recurrent cytogenetic abnormalities have been identified in CLL).

Diagnostic evaluation of patients with NHL included the following (15): history-taking (night sweats, weight loss, fever; neurologic, musculoskeletal or gastrointestinal symptoms); physical examination (lymphadenopathy; pericardial rub, pleural effusion, breast masses; hepatosplenomegaly, bowel obstruction, renal mass, and testicular or ovarian mass; spinal cord compression); biopsy of peripheral lymphadenopathy (excisional biopsy); computerized tomography scan of the neck, chest, abdomen and pelvis (to detect enlarged lymph nodes and hepatosplenomegaly and for initial staging and assessment of treatment response); bilateral bone marrow aspirate and biopsy (trephine biopsy should always be carried out if a diagnosis of lymphoma is suspected); complete blood count (peripheral blood lymphocytosis with circulating 
malignant cells is common in low-grade lymphoma); general chemistry panel (including determination of lactate dehydrogenase level, which is mandatory); HBV and HCV panels (especially in patients anticipated to receive monoclonal antibody therapy and/or chemotherapy); and HIV testing (for association).

\section{Controls}

An equal number of adult controls ( $n$ $=130$ ) were recruited, matched to the cases according to age and sex. The criteria for selection were being physically and mentally capable of participating and free from cancer and lymphadenopathy on clinical examination. They were sampled from among all patients of the department of orthopaedics, Menoufia University Hospital who were arriving with fractures after accidents; $88 \%$ of the eligible controls who were contacted agreed to participate in the study. They would be representative of the source population of the cases by region, since both the oncology and orthopaedic departments of the hospital serve patients from the same area. On the other hand, the risk of exposure to pesticides and to fractures are very likely to be independent.

Verbal informed consent was obtained from all participants in the study. Ethical approval to perform the study was obtained from the ethics committee in the Faculty of Medicine, University of Menoufia and the management board of the hospital.

\section{Data collection}

All cases and controls were given a questionnaire and serological analysis.

\section{Questionnaire}

Questionnaires have been used successfully to assess chronic pesticide exposure among farmers, farm workers and the general population, as long-lived biological markers are not available (16). A predesigned questionnaire was prepared and validated by the researchers and was pilot tested on 15 patients and 15 controls (out of the participants) at the Hospital to test reliability. Modifications were made according to the results obtained. The questionnaire was administered to all participants in a face-to-face interview that lasted 20-30 minutes. The interview was conducted at the hospital by the researchers and 2 well-trained nurses from the hospital who were blind to the study groups. In order to avoid recall bias that occurred after diagnosis of the cases and to allow a minimum latency period, a period of 1 year before the reference date (date of diagnosis) for both cases and controls was used as the duration of recorded exposure.

The questionnaire included the following items:

- Sociodemographic data (age, sex, residence, marital status, level of education, and occupation). Occupation was defined as ever held the occupation if respondents worked for at least 1 year in that occupation.

- Family history of malignancies in any first-degree relatives, if it could be accurately recalled by the participants.

- History of exposure to pesticides (yes/no): types of pesticides (to assist participants in recalling the pesticides used, a list of the most common brand names was provided); duration of exposure to pesticides; application method used most often; and use of protective equipment. In this study, the term pesticide referred primarily to herbicides, insecticides and fungicides, which are the commonest types used in Egypt. The duration of pesticide use was categorized into 2 groups based on the median years of exposure among subjects who used insecticides ( $\leq 5$ and $>5$ years). Information on habits such as changing clothes before entering the house, smoking and eating during application of pesticides and accidents (e.g. accidental poisoning) were recorded. Non-occupational use of pesticides (home, garden) was also included.
- History of exposure to various environmental risk factors, e.g. smoking, $\mathrm{X}$-rays, malaria infection, hair dyes.

\section{Serological analysis}

Blood samples were taken from participants and serological analysis was carried out for anti-HVC antibodies in serum. Anti-HCV was detected by 3rd-generation enzyme-linked immunosorbent assay (ELISA) (Innotest kit, Innogenetics). This qualitatively determines the presence of antibodies to 4 recombinant $\mathrm{HCV}$ proteins in serum. The test was done at the laboratory of the National Liver Institute.

\section{Statistical analysis}

The results were collected, tabulated and statistically analysed using SPSS statistical package, version 11 . The data are presented as descriptive statistics and the chi-squared test was done to study the association between qualitative variables, with Fisher exact test done when more than $25 \%$ of the cells contained an expected count $<5$. A stepwise logistic regression analysis was done to determine the adjusted odds ratio (OR) and 95\% confidence interval $(\mathrm{CI})$ for the different risk factors and malignancy. $P$ value $<0.05$ was considered statistically significant.

\section{Results}

\section{Background data}

The mean age of patients with lymphoproliferative disorders was 46.9 years, and for those with NHL the mean age was 47.5 years. There were more males than females among the cases $(59.2 \%$ versus $40.8 \%)$ and a high proportion lived in rural areas (60.8\%). One-third worked as farmers (32.3\%). Table 1 shows that there were no statistically significant differences between patients with lymphoproliferative disorders and controls regarding age, sex, residence, level of education and occupation $(P>0.05)$. Most of the females among the cases and controls were housewives. 


\begin{tabular}{|c|c|c|c|c|c|c|c|c|}
\hline \multirow{2}{*}{$\begin{array}{l}\text { Sociodemographic data } \\
\text { Age (years) }\end{array}$} & \multicolumn{2}{|c|}{$\begin{array}{l}\text { LPD cases } \\
\qquad(n=130)\end{array}$} & \multicolumn{2}{|c|}{$\begin{array}{l}\text { Controls } \\
(n=130)\end{array}$} & \multicolumn{2}{|c|}{$\begin{array}{c}\text { Total } \\
(n=260)\end{array}$} & \multirow[t]{2}{*}{$\begin{array}{c}\text { Test of } \\
\text { significance }\end{array}$} & \multirow[t]{2}{*}{$P$-value } \\
\hline & & & & & & & & \\
\hline Mean (SD) & \multicolumn{2}{|c|}{46.9 (10.9) } & \multicolumn{2}{|c|}{$48.3(9.8)$} & \multicolumn{2}{|c|}{$47.6(10.3)$} & $t=1.11$ & $>0.05$ \\
\hline \multirow[t]{2}{*}{ Range } & \multicolumn{2}{|c|}{$23-74$} & \multicolumn{2}{|c|}{$26-71$} & \multicolumn{2}{|c|}{$23-74$} & & \\
\hline & No. & $\%$ & No. & $\%$ & No. & $\%$ & & \\
\hline \multicolumn{9}{|l|}{ Sex } \\
\hline Male & 77 & 59.2 & 81 & 62.3 & 158 & 60.8 & & $>0.05$ \\
\hline Female & 53 & 40.8 & 49 & 37.7 & 102 & 39.2 & & \\
\hline \multicolumn{9}{|l|}{ Residence } \\
\hline Urban & 51 & 39.2 & 46 & 35.4 & 97 & 37.3 & $\chi^{2}=0.41$ & $>0.05$ \\
\hline Rural & 79 & 60.8 & 84 & 64.6 & 163 & 62.7 & & \\
\hline \multicolumn{9}{|l|}{ Marital status } \\
\hline Never married & 14 & 10.8 & 11 & 8.5 & 25 & 9.6 & $\chi^{2}=0.39$ & $>0.05$ \\
\hline Ever married & 116 & 89.2 & 119 & 91.5 & 224 & 86.2 & & \\
\hline \multicolumn{9}{|l|}{ Education level } \\
\hline Illiterate & 44 & 33.8 & 42 & 32.3 & 86 & 33.1 & & \\
\hline Primary education & 43 & 33.1 & 45 & 34.6 & 88 & 33.8 & $\chi^{2}=1.22$ & $>0.05$ \\
\hline Secondary education & 32 & 24.6 & 36 & 27.7 & 68 & 26.2 & & \\
\hline University and above & 11 & 8.5 & 7 & 5.4 & 18 & 6.9 & & \\
\hline \multicolumn{9}{|l|}{ Occupation } \\
\hline Farmer & 42 & 32.3 & 29 & 22.3 & 71 & 27.3 & $\chi^{2}=3.27$ & $>0.05$ \\
\hline Non-farmer & 88 & 67.7 & 101 & 77.7 & 189 & 72.7 & & \\
\hline
\end{tabular}

$S D=$ standard deviation

\section{Risk factors for all lymphoproliferative disorders}

A history of exposure to pesticides was reported by $38.5 \%$ of patients with lymphoproliferative disorders compared with $26.2 \%$ of controls and this was a significant difference $\left(\chi^{2}=4.50, P<\right.$ $0.05)$. Of those exposed to pesticides, significantly more of the cases of lymphoproliferative disorders had a long duration of exposure ( $>5$ years) than the controls ( $86.0 \%$ versus $64.7 \%)\left(\chi^{2}=\right.$ $4.10, P<0.05$ ) (Table 2). No statistically significant differences were found between patients with lymphoproliferative disorders and controls regarding types of pesticide exposure, the main crops sprayed, use of protective measures, and history of regular use of household insecticides $(P>0.05)$ (Table 2).

Regarding other risk factors, infection with HCV was significantly associated with lymphoproliferative disorders
(39.2\% of cases versus $21.5 \%$ of controls $)\left(\chi^{2}=9.62, P<0.01\right)$. None of the other studied variables - family history of cancer, exposure to X-rays, smoking and use of hair dyes - were found to be risk factors for lymphoproliferative disorders $(P>0.05)$ (Table 3$)$.

History of exposure to pesticides and HCV infection were still significantly associated with lymphoproliferative disorders after adjustment for age, sex and residence $(\mathrm{OR}=2.24 ; 95 \%$ CI: $1.22-4.11$ and $\mathrm{OR}=2.67$; $95 \% \mathrm{CI}$ : 1.50-4.80 respectively) (Table 4).

\section{Risk factors for non-Hodgkin lymphoma}

Similar results were found when analysing the cases of NHL separately. A significant association was shown between NHL and a history of exposure to pesticides (41.1\% of cases versus $26.2 \%$ of controls) $\left(\chi^{2}=5.95, P<0.05\right)$ and between NHL and HCV infection (40.2\% of cases versus $21.5 \%$ of controls) ( $\chi^{2}=$ $9.73, P<0.01)($ Table 5$)$. These associations were retained after adjustment for age, sex and residence ( $O R=2.46 ; 95 \%$ CI: 1.31-6.63) for exposure to pesticides and $(\mathrm{OR}=2.78$; 95\% CI: $1.51-5.14$ for HCV infection) (Table 6).

\section{Risk factors for leukaemia}

No significant association was found with history of exposure to pesticides nor with $\mathrm{HCV}$ infection when analysing the cases of CLL separately $(P>0.05)$ (Table 7). Also, neither family history of cancer nor history of smoking were risk factors for CLL $(P>0.05)$.

\section{Discussion}

The etiology of NHL and leukaemia is still largely unknown, but exposure to chemicals, in particular pesticides, has been suggested to be a risk factor (17). 


\begin{tabular}{|c|c|c|c|c|c|c|}
\hline \multirow[t]{2}{*}{ Risk factor } & \multicolumn{2}{|c|}{$\begin{array}{l}\text { LPD cases } \\
(n=130)\end{array}$} & \multicolumn{2}{|c|}{$\begin{array}{l}\text { Controls } \\
(n=130)\end{array}$} & \multirow[t]{2}{*}{$x^{2}$} & \multirow[t]{2}{*}{$P$-value } \\
\hline & No. & $\%$ & No. & $\%$ & & \\
\hline \multicolumn{7}{|l|}{ History of exposure to pesticides } \\
\hline Yes & 50 & 38.5 & 34 & 26.2 & 4.50 & \multirow{2}{*}{$<0.05$} \\
\hline No & 80 & 61.5 & 96 & 73.8 & & \\
\hline \multicolumn{7}{|l|}{ If yes: } \\
\hline Duration of exposure to pesticides (years) & \multicolumn{2}{|c|}{$(n=50)$} & \multicolumn{2}{|c|}{$(n=34)$} & & \\
\hline$\leq 5$ & 7 & 14.0 & 12 & 35.3 & 4.10 & $<0.05$ \\
\hline$>5$ & 43 & 86.0 & 22 & 64.7 & & \\
\hline \multicolumn{7}{|l|}{ Used protective measures } \\
\hline Always & 2 & 4.0 & 2 & 5.9 & \multirow{3}{*}{1.09} & \multirow{3}{*}{$>0.05$} \\
\hline Sometimes & 3 & 6.0 & 4 & 11.8 & & \\
\hline Never & 45 & 90.0 & 28 & 82.4 & & \\
\hline \multicolumn{7}{|l|}{ Type of pesticide } \\
\hline Crop insecticide & 29 & 58.0 & 22 & 62.9 & \multirow[t]{4}{*}{2.27} & \multirow[t]{4}{*}{$>0.05$} \\
\hline Herbicide & 10 & 20.0 & 6 & 17.2 & & \\
\hline Fungicide & 7 & 14.0 & 2 & 5.7 & & \\
\hline Home pesticide & 4 & 8.0 & 4 & 14.3 & & \\
\hline
\end{tabular}

The mean age of patients with lymphoproliferative disorders in the present study was 46.9 years ( 47.5 years among NHL patients). These results are similar to observations in previous studies of NHL in Egypt $(18,19)$ and in Turkey $(20)$. The male: female ratio in lymphoproliferative disorder cases was 1.45:1 (1.43:1 among NHL patients). This male predominance could be explained by men's greater exposure to the environmental risk factors at work. The reported male:female ratio among NHL cases varies around the world, but is consistently greater than 1 . In the USA, it is approximately (1.6:1) and in some countries it is greater than 2:1 (19).

Residence in rural areas was predominant among the cases (60.8\%). This could be explained by the fact that the department of oncology at Menoufia University Hospital serves mainly patients coming from the Delta region of Elyot, which has more rural than urban areas. This contrast with a previous study conducted at the
National Cancer Institute in Cairo, the capital city of Egypt (18), as cases were mainly coming from Cairo, Giza, and Alexandria Governorates, which have more urban than rural areas.

In the present study, farmers showed a higher risk of lymphoproliferative disorders compared with all other occupations (32.3\% of lymphoproliferative disorder cases were farmers versus $22.3 \%$ of controls), although the difference did not reach statistical significance. Attention has focused on farmers in studies of malignant lymphoma because they experience certain exposures, including exposure to zoonoses, pesticides and other chemicals such as fertilizers and solvents (21). Our finding was consistent with similar studies in Spain (22), France (23) and Sweden (24).

Exposure to pesticides in this study was significantly associated with lymphoproliferative disorders in the multivariate analysis. This risk was increased with duration of exposure to pesticides $>5$ years. A significant association was reported for NHL patients in univariate and multivariate analysis $(\mathrm{OR}=2.46)$. The mechanism of pesticide-induced carcinogenicity is still unclear. It has been suggested that alteration of immune function (25) or genetic factors $(6,26)$ may be responsible for the carcinogenesis associated with exposure to some pesticides. Also in Egypt, Loffredo et al. found that cases of NHL showed a significantly higher frequency of exposure to organophosphate insecticides than did controls $(\mathrm{OR}=2.5)$ (27). Similar results were also obtained in a study in the Islamic Republic of Iran in which the authors concluded that persons with exposure to any pesticide had increased risk of NHL than controls $(\mathrm{OR}=3.9)(10)$. However, another large study In the USA of pesticide exposure did not find any association between organophosphate use and NHL (28). It may be that different organophosphate pesticides have different effects, but unfortunately we had did not have sufficient numbers of subjects to analyse specific types 


\begin{tabular}{|c|c|c|c|c|c|c|}
\hline \multirow[t]{2}{*}{ Studied risk factor } & \multicolumn{2}{|c|}{$\begin{array}{l}\text { LPD cases } \\
(n=130)\end{array}$} & \multicolumn{2}{|c|}{$\begin{array}{l}\text { Controls } \\
(n=130)\end{array}$} & \multirow[t]{2}{*}{$x^{2}$} & \multirow[t]{2}{*}{$P$-value } \\
\hline & No. & $\%$ & No. & $\%$ & & \\
\hline \multicolumn{7}{|l|}{ Anti-HCV } \\
\hline +ve & 51 & 39.2 & 28 & 21.5 & 9.62 & $<0.01$ \\
\hline- ve & 79 & 60.8 & 102 & 78.5 & & \\
\hline \multicolumn{7}{|l|}{$\begin{array}{l}\text { Family history of cancer (in 1st-degree } \\
\text { relatives) }\end{array}$} \\
\hline Yes & 32 & 24.6 & 21 & 16.2 & 2.87 & $>0.05$ \\
\hline No & 98 & 75.4 & 109 & 83.8 & & \\
\hline \multicolumn{7}{|l|}{ Type of relatives' cancer } \\
\hline Lymphoheamapoietic malignancies & 5 & 3.8 & 1 & 0.8 & & $>0.05$ \\
\hline Other & 27 & 20.8 & 20 & 15.4 & 0.60 & \\
\hline \multicolumn{7}{|l|}{ History of exposure to X-rays } \\
\hline Yes & 42 & 32.3 & 50 & 38.5 & 1.07 & $>0.05$ \\
\hline No & 88 & 67.7 & 80 & 61.5 & & \\
\hline \multicolumn{7}{|l|}{ History of smoking } \\
\hline Yes & 51 & 39.2 & 44 & 33.8 & 0.81 & $>0.05$ \\
\hline No & 79 & 60.8 & 86 & 66.2 & & \\
\hline \multicolumn{7}{|l|}{ History of using hair dyes } \\
\hline Yes & 12 & 9.2 & 9 & 6.9 & 0.47 & $>0.05$ \\
\hline No & 118 & 90.8 & 121 & 93.1 & & \\
\hline
\end{tabular}

HCV = hepatitis C virus.

of organophosphates. Another study, in Sweden, found no significant associations between NHL and either organochlorine or organophosphate insecticides (29).

No significant association was observed in this study between the CLL and history of exposure to pesticides in agriculture. This could be due to the small number of leukaemia patients in the sample $(n=23)$. A study conducted in Greece found an association of pesticide exposure with leukaemia $(\mathrm{OR}=2.14)$ (30). Similar results were obtained from 6 European countries, which found that the risk of CLL was elevated among those ever exposed to inorganic $(\mathrm{OR}=1.6)$ and organic pesticides $(\mathrm{OR}=1.5)$. CLL risk was highest amongst those ever exposed to organophosphates $(\mathrm{OR}=2.7)(31)$.

In our study, infection with HCV was associated with an increased risk of developing lymphoproliferative disorders in multivariate analysis, after adjustment for age, sex, residence and history of exposure to pesticides (OR =2.67). Also, HCV was found to be a risk factor for NHL in the multivariate analysis $(\mathrm{OR}=2.78)$. However, no significant association was found between HCV infection and CLL, which

\begin{tabular}{|c|c|c|}
\hline Studied risk factor & $\mathrm{OR}^{\mathrm{a}}(95 \% \mathrm{CI})$ & $P$-value \\
\hline History of exposure to pesticides & $2.24(1.22-4.11)$ & $<0.05$ \\
\hline HCV infection & $2.67(1.50-4.80)$ & $<0.01$ \\
\hline
\end{tabular}

${ }^{a}$ Adjusted for age, sex and residence. Variables included in logistic regression were exposure to pesticides and HCV infection.

$H C V=$ hepatitis $C$ virus; $O R=$ odds ratio; $C l=$ confidence interval. again could be due to the small number of leukaemia patients.

A significant association between HCV infection and NHL was previously observed in Egypt (18) and in British Columbia, Canada (32). This association had been hypothesized to be due to the persistence of chronic HCV in lymphocytes along with the involvement of genetic and environmental factors (33). Possible mechanisms for malignant transformation include clonal proliferation of B-cells, inhibition of apoptotic cell death or both (34). Polymorphisms in the oxidative stress regulatory enzyme genes GPX1 and MPO may influence NHL risk in HCV-infected Egyptian patients (35).

In contrast, other studies, conducted in France (36), Canada (37) and India (38,39), found no or weak association between HCV infection and subtypes of NHL. These studies were limited by small sample sizes and 


\begin{tabular}{|c|c|c|c|c|c|c|}
\hline \multirow[t]{2}{*}{ Risk factor } & \multicolumn{2}{|c|}{$\begin{array}{l}\text { NHL cases } \\
(n=107)\end{array}$} & \multicolumn{2}{|c|}{$\begin{array}{l}\text { Controls } \\
(n=130)\end{array}$} & \multirow[t]{2}{*}{$x^{2}$} & \multirow[t]{2}{*}{$P$-value } \\
\hline & No. & $\%$ & No. & $\%$ & & \\
\hline \multicolumn{7}{|c|}{$\begin{array}{l}\text { History of exposure to pesticides in } \\
\text { agriculture }\end{array}$} \\
\hline Yes & 44 & 41.1 & 34 & 26.2 & 5.95 & $<0.05$ \\
\hline No & 63 & 58.9 & 96 & 73.8 & & \\
\hline \multicolumn{7}{|l|}{ Anti-HCV } \\
\hline$+v e$ & 43 & 40.2 & 28 & 21.5 & 9.73 & $<0.01$ \\
\hline ve & 64 & 59.8 & 102 & 78.5 & & \\
\hline
\end{tabular}

HCV $=$ hepatitis $C$ virus

hence lacked adequate power, or had study populations with a low prevalence of $\mathrm{HCV}$ carriage, and hence have only been able to identify a weak association. It is also possible that there may be a geographical variations in the association, with co-factors such as geographical differences in viral genotype, population genetics or endifferences between studies.

In our study, we observed that the risk of having lymphoproliferative disorders was greater with $\mathrm{HCV}$ infection $(\mathrm{OR}=2.67)$ than with pesticides exposure $(\mathrm{OR}=2.24)$. This might be explained by the high prevalence of HCV infection in Egypt. The Egypt Demographic and Health Survey 2008 concluded that Egypt has the highest prevalence of $\mathrm{HCV}$ in the world, estimated nationally at $14.7 \%$ (40).

In this study, family history of cancer in a first-degree relative and type of relatives' cancer showed no significant association with lymphoproliferative disorders. This could be because the vironmental factors underlying the

information on family history was selfreported and may therefore be inaccurate. This result disagrees with studies in Italy (41) and the USA (42), which reported a significant association between lymphoproliferative disorders and family history of malignancies in first-degree relatives $(\mathrm{OR}=1.6$ and 2.2 respectively).

A history of smoking was not found to be risk factor for lymphoproliferative disorders in our study. Similar results have been reported in the United Kingdom (43) and the USA (44). In contrast to our results, a significant association between tobacco smoke and lymphoid neoplasms has been reported in Italy (45) and the USA (46), but these studies were unable to show a dose-response relationship, leaving limited support for a causal association.

In the present study, no significant association was found between lymphoproliferative disorders and history of using hair dyes. In contrast, a study conducted in Europe found a

\begin{tabular}{|c|c|c|}
\hline Risk factor & $\mathrm{OR}^{\mathrm{a}}(95 \% \mathrm{Cl})$ & $P$-value \\
\hline Exposure to pesticides in agriculture & $2.46(1.31-6.63)$ & $<0.01$ \\
\hline HCV infection & $2.78(1.51-5.14)$ & $<0.01$ \\
\hline
\end{tabular}

${ }^{a}$ Adjusted for age, sex and residence. Variables included in logistic regression were $\mathrm{HCV}$ and history of exposure to pesticides.

$H C V=$ hepatitis $C$ virus; $O R=$ odds ratio; $C I=$ confidence interval. significant association between the use of hair dyes and lymphoid neoplasms $(\mathrm{OR}=1.19)$, as hair dye formulations have long been known to contain mutagenic chemicals (47). This difference in the results between the studies could be explained by the fact that $60.8 \%$ of our patients were resident in rural areas where the frequent use of hair dyes is not a common practice.

This study also showed no significant association between lymphoproliferative disorders and history of exposure to X-rays, which could be due to the fact that exposure to X-rays is mainly a risk factor for leukaemia, and cases of CLL accounted only about one-fifth of our total sample (23/130). A similar finding was reported in the USA (48).

One of the limitations of the current study was that pesticide exposure was self-reported by the participants and this might bias the results. Also, the small sample size of CLL cases might lead to inaccurate results regarding risk factors for leukaemia. Case-control studies are prone to bias, especially selection, recall and inter-interviewer bias, even though measures were taken to minimize this, as described earlier. A final limitation of our study was the use of simple regression analysis instead of conditional regression analysis. However, we kept the stratum sizes large to minimize this effect. 


\begin{tabular}{|c|c|c|c|c|c|c|}
\hline \multirow[t]{2}{*}{ Risk factor } & \multicolumn{2}{|c|}{$\begin{array}{l}\text { CLL cases } \\
(n=23)\end{array}$} & \multicolumn{2}{|c|}{$\begin{array}{l}\text { Controls } \\
(n=130)\end{array}$} & \multirow[t]{2}{*}{$x^{2}$} & \multirow[t]{2}{*}{$P$-value } \\
\hline & No. & $\%$ & No. & $\%$ & & \\
\hline \multicolumn{7}{|c|}{ History of exposure to pesticides } \\
\hline Yes & 6 & 26.1 & 34 & 26.2 & 0.00 & $>0.05$ \\
\hline No & 17 & 73.9 & 96 & 73.8 & & \\
\hline \multicolumn{7}{|l|}{ Anti-HCV } \\
\hline +ve & 8 & 34.8 & 28 & 21.5 & 1.91 & $>0.05$ \\
\hline -ve & 15 & 65.2 & 102 & 78.5 & & \\
\hline
\end{tabular}

HCV = hepatitis $C$ virus.

In conclusion, pesticide exposure and HCV infection were found to be risk factors for lymphoproliferative disorders, including NHL but not leukaemia, in adults. This risk was greatest when the duration of exposure to pesticides was greater than 5 years. More research on a large scale is needed, integrating various types of studies, such as surveillance for type pesticide product use, development and application of new biomarkers for pesticide exposure and subtypes of NHL.

Competing interests: None declared.

\section{References}

1. Mahima VG, Patil K, Raina A. Extranodal non-Hodgkin's lymphoma. An unfamiliar presentation in the oral cavity: a case report. Int J Clin Cases Invest, 2010;1(1):1-6.

2. Soliman AS, Boffetta P. Lymphoma and leukemia. In: Freedman LS, Edwards BK, Ries LAG, Young JL, editors. Cancer incidence in the four member countries (Cyprus, Egypt, Israel, and Jordan) of the Middle East Cancer Consortium (MECC) compared with US SEER. Bethesda (MD): National Cancer Institute; 2006. pp. 131-40.

3. Curado MP, Edwards B, Shin HR, Storm H, J. Ferlay, Heanue $\mathrm{M}$, et al. Cancer incidence in five continents. Volume 9. Lyon, France: International Agency for Research on Cancer; 2007. p. 101.

4. Wall DA. Lymphoproliferative disorders. Medscape [Internet]. Updated: 12 Mar 2012 (http://emedicine.medscape.com/ article/987765-overview, accessed 9 April 2014).

5. Fisher SG, Fisher RI. The epidemiology of non-Hodgkin's lymphoma. Oncogene. 2004;23(38):6524-34.

6. Armitage JO, Longo DL. Malignancies of lymphoid cells. In: Kasper DL, Braunwald E, Fauci A, Hauser S, Longo D, Jameson J.L, editors. Harrison's principles of internal medicine. New York (NY): McGraw Hill; 2005. pp. 641-655.

7. Pagano JS, Blaser M, Buendia MA, Damania B, Khalili K, RaabTraub N, et al. Infectious agents and cancer: criteria for a causal relation. Semin Cancer Biol. 2004 Dec;14(6):453-71.

8. Agriculture Pesticide Committee. Cairo, Egypt: Ministry of Agriculture and Land Reclamation, 2010 [Internet] (http:// www.apc.gov.eg/en/products/showall.aspx, accessed 9 April 2014).

9. Badawy M. Use and impact of pesticides in Egypt. Int J Environ Health Res. 1998;8(3):223-39.

10. Zakerinia $M$, Namdari $M$, Amirghofran $S$. The relationship between exposure to pesticides and the occurrence of lymphoid neoplasm. Iran Red Crescent Med J. 2012;14(6):337-44.

11. Chiu B, Weisenburger D, Zahm S, Cantor K. Agricultural pesticide use, familial cancer, and risk of non-Hodgkin lymphoma. Cancer Epidemiol Biomarkers Prev. 2004;13(4):525-31.
12. Dreiher J, Kordysh E. Non-Hodgkin lymphoma and pesticide exposure: 25 years of research. Acta Haematol. 2006;116:15364.

13. Fritschi L, Benke G, Hughes A. Occupational exposure to pesticides and risk of non-Hodgkin's lymphoma. Am J Epidemiol. 2005;162(9):849-57.

14. Mueller NE. Hodgkin's disease. In: Schottenfeld D, Fraumeni JF Jr, editors. Cancer epidemiology and prevention. 2nd ed. New York: Oxford University Press; 1996. p. 893-919.

15. Greer JP, Williams ME. Non-Hodgkin lymphoma in adults. In: Greer JP, Foerster J, Rodgers GM, et al., editors. Wintrobe's Clinical hematology. 12th ed. Philadelphia (PA): Lippincott Williams and Wilkins; 2009. p. 2144-94.

16. Alavanja MCl, Hoppin JA, Kamel F. Health effects of chronic pesticide exposure: cancer and neurotoxicity. Annu Rev Public Health. 2004;25:155-97.

17. Miligi L, Costantini A, Bolejack V. Non-Hodgkin's lympho$\mathrm{ma}$, leukemia, and exposures in agriculture: results from the Italian multicenter case-control study. Am J Ind Med. 2003;44(6):627-36.

18. Cowgill K, et al. Case-control study of non-Hodgkin's lymphoma and hepatitis C virus infection in Egypt. Int J Epidemiol. 2004;33(5):1034-9.

19. Abdel-Fattah MM, Yassine OG. Non-Hodgkin's lymphomas in Alexandria, Egypt; incidence rates and trend study (19952004). Eur J Cancer Prev. 2007 Oct;16(5):479-85.

20. Paydas S, Kilic B, Bugdayci R. Prevalence of hepatitis C virus infection in patients with lymphoproliferative disorders in Southern Turkey. Br J Cancer. 1999;80:1303-5.

21. Mester B, et al. Occupation and malignant lymphoma: a population based case control study in Germany. BMJ. 2006;63:1726.

22. Evan B, et al. Exposure to non-arsenic pesticides is associated with lymphoma among farmers in Spain. Occup Environ Med. 2006 October;63(10):663-8.

23. Orsi L, Troussard X, Monnereau A, Berthou C, Fenaux $\mathrm{P}$, Marit $\mathrm{G}$, et al. Occupation and lymphoid malignancies: re- 
sults from a French case-control study. Occup Environ Med. 2007;49(12):1339-50.

24. Hardell L, Eriksson M, Nordstrom M. Exposure to pesticides as risk factor for non-Hodgkin's lymphoma and hairy cell leukemia: pooled analysis of two Swedish case-control studies. Leuk Lymphoma. 2002;43:1043-9.

25. Baris D, Zahm SH. Epidemiology of lymphomas. Curr Opin Oncol. 2000;12:383-93.

26. Chiu B, et al. Agricultural pesticide use and risk of $t$ (14;18)-defined subtypes of non-Hodgkin lymphoma. Blood. 2006;108:1363-9.

27. Loffredo C, et al. Increased risk for Non-Hodgkin's lymphoma associated with HCV and agricultural pesticides in Egypt. Epidemiology. 2003;14(5):43-4.

28. Tatham L, Tolbert P, Kjeldsberg C. Occupational risk factors for subgroups of non-Hodgkin's lymphoma. Epidemiology. 1997;8:551-8.

29. Persson B, Fredrikson M. Some risk factors for non-Hodgkin's lymphoma. Int J Occup Med Environ Health. 1999;12:135-42.

30. Maria K. Pesticide exposure and lymphohaematopoietic cancers: a case-control study in an agricultural region (Larissa, Thessaly, Greece). BMC Public Health. 2011;11:5.

31. Cocco P, Satta G, Dubois S, Pili C, Pilleri M, Zucca M, et al. Lymphoma risk and occupational exposure to pesticides: results of the Epilymph study. Occup Environ Med .2013;70(2):91-8.

32. Spinelli J, et al. Hepatitis C virus and risk of non-Hodgkin lymphoma in British Columbia, Canada. Int J Cancer. 2008;122(3):630-3.

33. Gisbert JP, García-Buey L, Arranz R, Blas C, Pinilla I, Khorrami $S$, et al. The prevalence of hepatitis $C$ virus infection in patients with non-Hodgkin's lymphoma. Eur J Gastroenterol Hepatol. 2004;16(2):135-8.

34. Machida $\mathrm{K}$, et al. Hepatitis $\mathrm{C}$ virus triggers mitochondrial permeability transition with production of reactive oxygen species, leading to DNA damage and STAT3 activation. J Virol. 2006;80(14):7199-207.

35. Farawela H, Khorshied M, Shaheen I, Gouda H, Nasef A, Abulata $\mathrm{N}$, et al. The association between hepatitis $\mathrm{C}$ virus infection, genetic polymorphisms of oxidative stress genes and B-cell non-Hodgkin's lymphoma risk in Egypt. Infect Genet Evol. 2012 Aug;12(6):1189-94.

36. Hausfater P, Cacoub P, Sterkers Y. Hepatitis C virus infection and lymphoproliferative diseases: prospective study on 1,576 patients in France. Am J Hematol. 2001;67:168-71.
37. Collier J, Zanke B, Moore M. No association between hepatitis C and B-cell lymphoma. Hepatology. 1999;29:1259-61.

38. Varma S, Menon MC, Garg A, Malhotra P, Sharma A, Chawla YK, et al. Hepatitis $C$ virus infection among patients with non-Hodgkin's lymphoma in northern India. Hepatol Int. 2011;5(2):688-92.

39. Dal Maso L, Franceschi S. Hepatitis C virus and risk of lymphoma and other lymphoid neoplasms: a meta-analysis of epidemiologic studies. Cancer Epidemiol Biomarkers Prev. 2006;15:2078-85.

40. El-Zanaty F, Way A. Egypt Demographic and Health Survey 2008. Cairo, Egypt: Ministry of Health, El-Zanaty and Associates, and Macro International; 2009.

41. Negri E, Talamini R, Montella M, Dal Maso L, Crispo A, Spina M, et al. Family history of hemolymphopoietic and other cancers and risk of non-Hodgkin's lymphoma. Cancer Epidemiol Biomarkers Prev. 2006;15(2):245-50.

42. Zhang Y, Wang R, Holford TR, Leaderer B, Zahm SH, Boyle P, et al. Family history of hematopoietic and non-hematopoietic malignancies and risk of non-Hodgkin lymphoma. Cancer Causes Control. 2007;18(4):351-9.

43. Willett EV, Smith AG, Dovey GJ. Tobacco and alcohol consumption and the risk of non-Hodgkin lymphoma. Cancer Causes Control. 2004;15(8):771-80.

44. Jesse D, et al. Associations between anthropometry, cigarette smoking, alcohol consumption, and non-Hodgkin lymphoma in the Prostate, Lung, Colorectal, and Ovarian Cancer Screening Trial. Am J Epidemiol. 2010 June;171(12):1270-81.

45. Talamini L, Polesel J, Montella M. Smoking and non-Hodgkin lymphoma: case-control study in Italy. Int J Cancer. 2005;115(4):606-10.

46. Diver WR, Patel AV, Thun MJ, Teras LR, Gapstur SM. The association between cigarette smoking and non-Hodgkin lymphoid neoplasms in a large US cohort study. Cancer Causes Control. 2012 Aug;23(8):1231-40.

47. Sanjose S, Benavente Y, Nieters A. Association between personal use of hair dyes and lymphoid neoplasms in European. Am J Epidemiol. 2006;164:47-55.

48. Boice JD Jr, Morin MM, Glass AG, Friedman GD, Stovall M, Hoover RN, et al. Diagnostic X-ray procedures and risk of leukemia, lymphoma, and multiple myeloma. JAMA. 1991 Mar 13;265(10):1290-4. 